\title{
Impact of land reclamation in Aiwan Cove on marine water quality in Zhejiang Province, China
}

\author{
Xiaochen Huang ${ }^{1}$, Jufei Qiu ${ }^{1}$, Shaojun Qi ${ }^{1}$, Hanling $\mathrm{Xu}^{2}$, Haiping Zhang ${ }^{2 \star}$ \\ ${ }^{1}$ Shanghai East Sea Marine Engineering Survey and Design Institute, Shanghai, China \\ ${ }^{2}$ College of Environmental Science and Engineering, Tongji University, Shanghai, China \\ *Corresponding author, hpzhang@tongji.edu.cn
}

\begin{abstract}
Keywords:Land reclamation; water quality; modelling; Aiwan Cove
Abstract. A coupled hydrodynamic and water quality model based on MIKE 21 software was established to investigate the impact of land reclamation in Aiwan Cove, Zhejiang Province. The model was calibrated with the tidal level and current speed and direction measurements in the project area in 2013. The results showed that agricultural activities on the 1792 ha of the reclaimed land would cause severe water quality degradation of one class lower in nearly $3.69 \mathrm{~km}^{2}$ of sea area in the case of one year return storm events. The pollutant transport is largely controlled by the local hydrodynamic conditions. The influenced area was larger if the runoff discharge occurred during the neap tide than during the spring tide, and if the runoff discharge occurred in the low tide period when the water depth was small. It is suggested that additional pollution control measures should be conducted on the land and the runoff discharge timing be considered as well.
\end{abstract}

\section{Introduction}

The coastal areas of south-eastern China are the main force engine of China's economic growth and land reclamation has been playing an important role in economic booming in the area. For example, Zhejiang Province has planned to reclaim half million mu (about 33,333 ha) of mudflats during the five years of 2013 to 2017[1]. Land reclamation will cause negative impacts on marine ecology. The extent of the impact and its human health significance is influenced by numerous factors, including prevailing ocean currents, in-water pollutant transformation processes, and the timing, magnitude and nature of pollutants discharged from the land[2]. Until recently, effluent from sewage treatment plants was often the primary source of coastal pollution, including nutrients, pathogens, pesticides, and heavy metals. However, pollutant loading from many sewage treatment plants has declined over the past decades due to improvements in civil infrastructure, pollutant source control and disposal/treatment technology. As a result, surface water runoff, in many cases, has supplanted sewage treatment plants as the primary source of pollutant loading to the sea[3].

The present study investigated the impact of land reclamation of Aiwan Cove on marine water quality in Zhejiang Province, China. 1792 ha of land will be claimed in the project, which will be utilized as farmland (1058 ha), water surface (339 ha) and infrastructures (road, etc., 395 ha). Rice andfruitswill be grown in the farmland and the surface water will be used for flood control and water quality buffering. All sewage generated on the reclaimed land will be collected and transported to an existing wastewater treatment plant located in other area. However, pollutants generated from agricultural activities on the reclaimed land will enter the surface water and eventually enter the ambient sea water, resulting in the degradation of sea water quality.

\section{Methodology}

A coupled two dimensional (2D) hydrodynamic and water quality model was established for the project area using MIKE 21 software developed by DHI Water and Environment, Denmark[4]. The MIKE 21 hydrodynamic model is based on the numerical solution of the depth-integrated incompressible Reynolds averaged Navier-Stokes equations with a flexible mesh approach. MIKE ECOLab is a generic and open tool for customising aquatic ecosystem models to describe physical, chemical and biological processes related to environmental problems and water pollution in coastal 
areas. The ECOLab is integrated with the advection-dispersion module which describes the physical transport processes covering the area of interest. The established model covers a large area to avoid the impact of open sea boundary conditions and to ensure that the impact of the project is within the computation domain, as shown in Fig. 1.

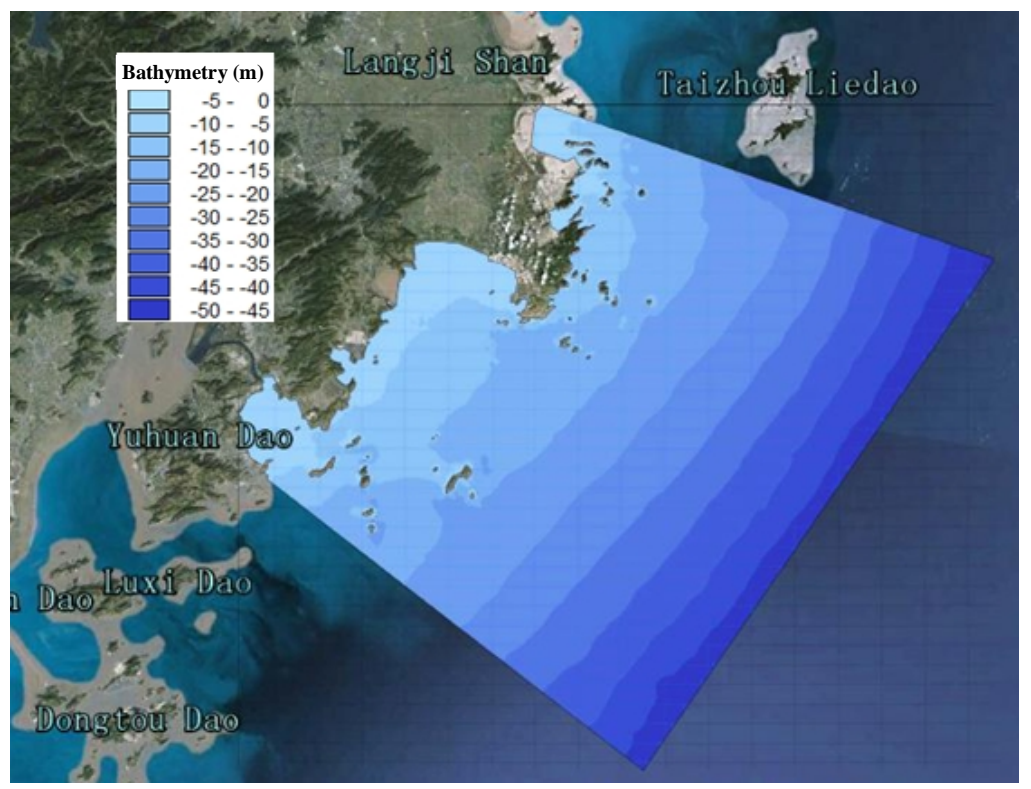

Figure 1 Model domain, bathymetry and the location of project area

The hydrodynamic model was calibrated with the tidal level and current velocity measurements in nine locations in the vicinity of the project area in April 2013, which represented the hydrodynamic characteristics of spring tide and neap tide in the area. In general, the simulation results agreed with the measurements well as shown in Fig. 2 and 3. The difference between the simulated and measured tidal level was within $10 \mathrm{~cm}$. The difference between the simulated and measured current magnitude and phase was within $8 \%$. The difference between the simulated and measured current direction was within 10 degrees.

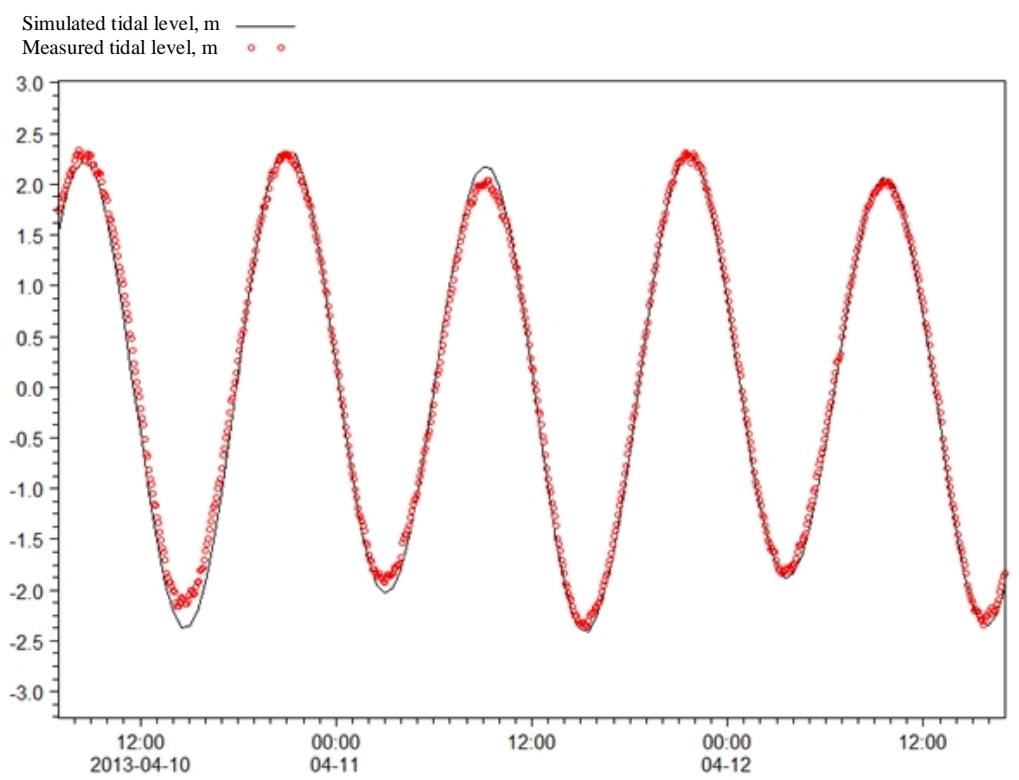

Figure 2 Simulated and measured tidal level at Diaobang Station 


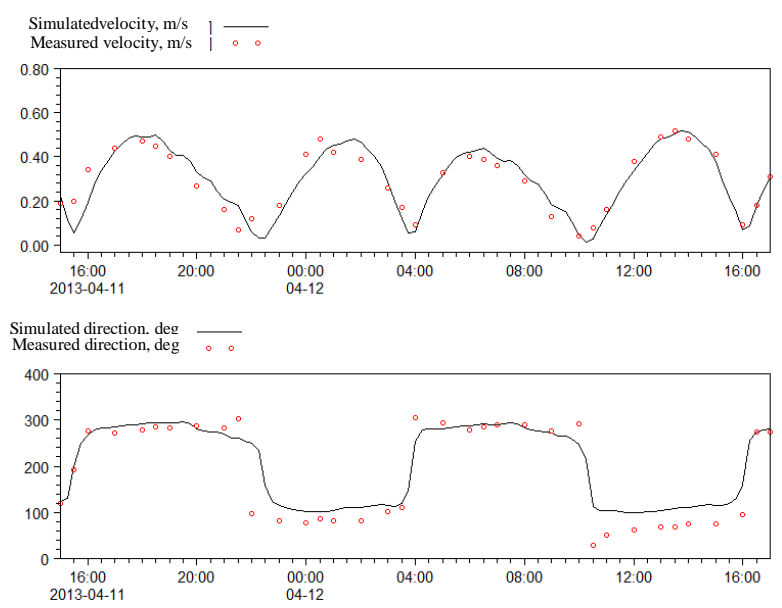

Figure 3 Simulated and measured current speed and direction at Station 1

The pollutants derived from the reclaimed land will be usually trapped in the surface water and will not enter the ambient sea. However, during storm events, the 2 gates connecting the surface water and the sea will be open and the pollutants will be released into the sea. The amount of pollutants that is released into the sea therefore depends on both the pollutant concentration of the surface water and flow discharge through the gates. In the present study, the impact of one year return storm with one hour duration was analysed. The average concentrations of the runoff are provided in Table 1. The concentrations were estimated based on the measurements in similar agricultural areas and manuals[5,6,7]. The decay coefficients are $0.06 / \mathrm{d}$ for $\mathrm{COD}, 0.1 / \mathrm{d}$ for $\mathrm{NH}_{3}-\mathrm{N}$, $0.04 / \mathrm{d}$ for $\mathrm{NO}_{3}-\mathrm{N}, 0.04 / \mathrm{d}$ for TN $0.04 / \mathrm{d}$, and $0.02 / \mathrm{d}$ for TP.

Table1 Average concentrations of the runoff $(\mathrm{mg} / \mathrm{L})$

\begin{tabular}{|c|c|c|c|c|c|}
\hline Parameter & $\mathrm{COD}$ & $\mathrm{NH}_{4}-\mathrm{N}$ & $\mathrm{NO}_{3}-\mathrm{N}$ & $\mathrm{TN}$ & $\mathrm{TP}$ \\
\hline Concentration & 2.86 & 0.65 & 1.26 & 2.19 & 0.14 \\
\hline
\end{tabular}

\section{Results and Discussion}

The hydrodynamic conditions of spring tide and neap tide in April 2003 were used for the water quality simulation. It was assumed that the background concentrations of the sea water were $0 \mathrm{mg} / \mathrm{L}$ to investigate the increment of concentration due to runoff discharge from the reclaimed land. Furthermore, it was assumed that the runoff discharge occurred during the high tide and low tide period when the hydrodynamic force was weak, which is not advantageous for pollutant dilution and transport. Fig. 4 is an example of the simulation results for the maximum COD concentration when the runoff discharge occurred in the low spring tide.

The simulation results showed that the pollutant transport was largely controlled by the local hydrodynamic conditions. As a result, the pollution plume travelled along south-north direction in the vicinity of the dyke and along southeast-northwest direction in the outer sea. It was found that the influenced area was larger if the runoff discharge occurred during the neap tide than during the spring tide, because the current velocity during the spring tide was larger, resulting in a stronger dilution of the pollutant with the ambient sea water. This was also the case if the runoff discharge occurred in the low tide period when the water depth was small.

According to the statistics of the modelling results, the concentration increment of $2 \mathrm{mg} / \mathrm{L}$ for COD is $1.11 \mathrm{~km}^{2}$, increment of $0.2 \mathrm{mg} / \mathrm{L}$ for $\mathrm{NH}_{4}-\mathrm{N}$ is $2.21 \mathrm{~km}^{2}$, increment of $0.2 \mathrm{mg} / \mathrm{L}_{\text {for }} \mathrm{NO}_{3}-\mathrm{N}$ is $3.01 \mathrm{~km}^{2}$, increment of $0.2 \mathrm{mg} / \mathrm{L}$ for TN is $3.69 \mathrm{~km}^{2}$, and increment of $0.015 \mathrm{mg} / \mathrm{L}$ for TP is 3.47 $\mathrm{km}^{2}$. The selection of the concentration increment was based on the actual concentration of the sea area so that the water quality would one class degradation according to the National Sea Water Quality Standard (GB 3097-1997). 1792 ha of land reclamation will cause severe water quality degradation of one class lower in nearly $4 \mathrm{~km}^{2}$ of sea area in the case of one year return storm 
events. It is therefore suggested that additional pollution control measures should be conducted on the land and the runoff discharge timing be considered as well.

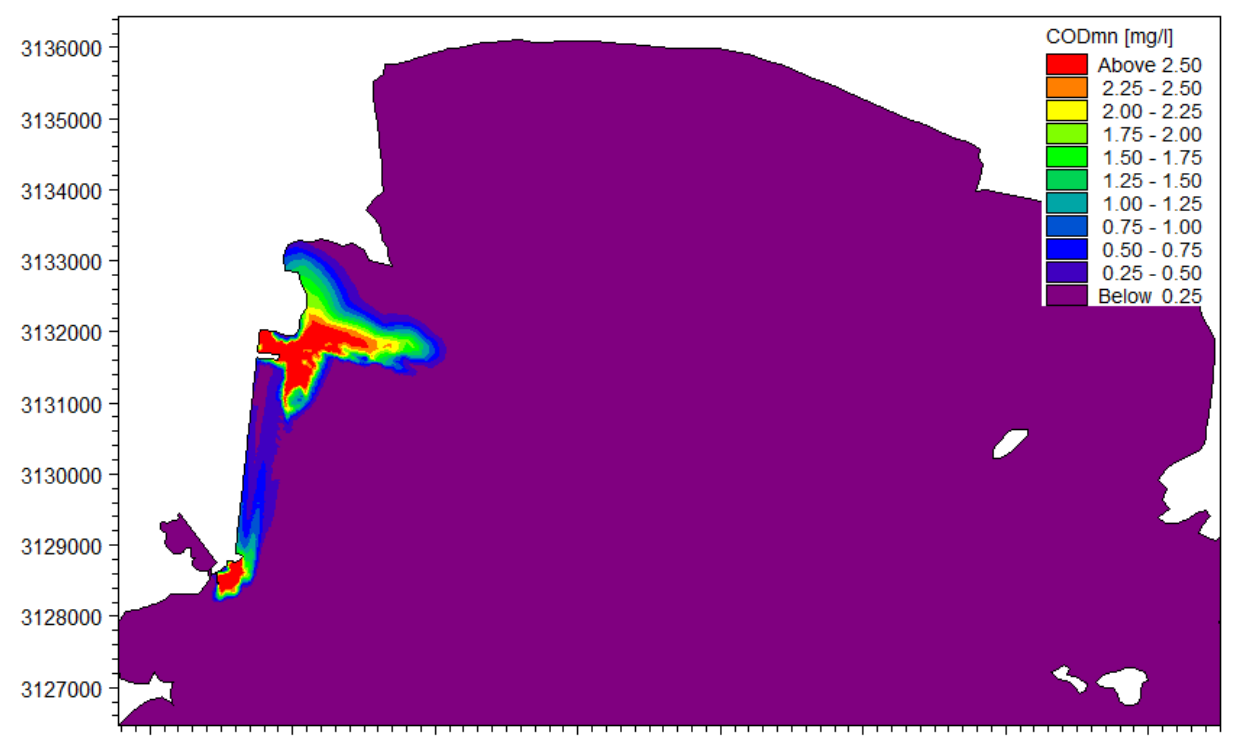

Figure 4 Maximum COD concentration when the runoff discharge occurred in the low spring tide

\section{Conclusions}

The impact of land reclamation in Aiwan Cove on sea water quality was investigated with a coupled hydrodynamic and water quality model based on MIKE 21 software. The results showed that agricultural activities on the 1792 ha of the reclaimed land would cause severe water quality degradation of one class lower in nearly $3.69 \mathrm{~km}^{2}$ of sea area in the case of one year return storm events. The pollutant transport is largely controlled by the local hydrodynamic conditions. The influenced area was larger if the runoff discharge occurred during the neap tide than during the spring tide, and if the runoff discharge occurred in the low tide period when the water depth was small. It is suggested that additional pollution control measures should be conducted on the land and the runoff discharge timing be considered as well.

\section{References}

[1] Office of development and Reform Commission of Zhejiang Province. Master Plan of Mudflats reclamation of Zhejiang Province (2005-2020), 2006

[2] H. Z. Xue, H. S. Hong, A. T. Chales. Cumulative environmental impacts and integrated coastal management: the case of Xiamen, China. Journal of Environmental Management, 2004. 71: 271-283

[3] S. Bay, B. H. Jones, K. Schiff, L. Washburn. Water quality impacts of stormwater discharges to Santa Monica Bay. Mar. Environ. Res. 2003, 56: 205-223

[4] DHI, MIKE 21 User Guide, DHI Water \& Environment, Denmark, 2015.

[5] X. B. Wang, L. D. Bailey, C. A. Grant. A review of fertilizer N behaviour in soils, and effective N management under conservation tillage systems. Program Soil Science. 1995, 23(2): 1-11.

[6] Chinese Academy on Environmental Planning. Technical Guidelines on the Determination of National Water Environment Assimilation Capacity, 2003.

[7] Bruce J. P., Wilfred M. W., Patrick J. M., et al. Control of Nitrogen Export from Watersheds by Headwater Streams. Science. 2001, 292(5514): 86-90. 